\title{
Ethnic Culture and Literature of Western Liao Dynasty*
}

\author{
Renxiong Gao \\ School of Art and Literature \\ Shihezi University \\ Shihezi, China
}

\begin{abstract}
Khitan people moved their dynasty from east to west, and eventually established the Western Liao Dynasty in the multi-ethnic areas of Central Asia. It continued the part of the Liao Dynasty, which was destroyed by the Jin Dynasty of Nvzhen people, and brought the northern culture of China to Central Asia. It was an important period in which Chinese culture influenced Central Asia and even Eastern Europe in history, and also a period that Chinese eastern culture greatly melted with Chinese western culture in history. Western Liao has a great influence on the world's cultural history, and it also enabled the western world to learn more about China. The literature bred in such a cultural soil is necessarily the interwoven literature of multi-ethnic cultures. We can see the general composition of the literature of the Western Liao Dynasty by investigating the history, jurisdiction territory and national culture of the Western Liao Dynasty. From the language and writing used in the Western Liao Dynasty, the literature of the Western Liao Dynasty can be divided into Chinese, Khitan, ancient Uyghur (Turkic) and other languages. From the cultural tendency, the literature of the Western Liao Dynasty includes political, religious and folk secular works. From the stylistic point of view, the literature of the Western Liao Dynasty takes poetry as its main body.
\end{abstract}

Keywords-the regime and territory of Western Liao Dynasty; ethnic religions; multi-lingual; literary form

\section{INTRODUCTION}

The Western Liao Dynasty $(114 \sim 1211)$ lasted for nearly a hundred years. During the reign of the Western Liao Dynasty, the rulers, guided by Confucianism, carried out the policy of "reducing the burden of taxation and cost" and "placating the outlying regions and the regions submitting to her", which created a stable social and political environment. At the same time, it brought the science and technology of the Central Plains to the Central Asia, which promoted the development of urban and agricultural settlements, and made the economic and cultural development of Central Asia considerable. It also appeared some important scholars and literati. The Western Liao Dynasty was an important dynasty in the history of Central Asia. It was the continuation of the Liao Dynasty in Northwest China after its westward

*This paper is one of the staged results of the major tendering project of the national social science foundation of China,

"Collation and Research of all Writings in the Western Regions of China", presided over by Gao Renxiong. (17ZDA263) migration. According to historical records, the culture of the Western Liao Dynasty was flourishing. It has made some achievements in literature, and has had a far-reaching impact in history. However, the academic researches on the literature of the Western Liao Dynasty and its culture are less. The academic circle is relatively vague on the concept of the literature of the Western Liao Dynasty. In view of this situation, the author tries to explain the literature of the Western Liao Dynasty under the unique historical and cultural background from the perspective of regional culture, and supplement the lack of understanding of the literature of the Western Liao Dynasty in the study of the literature of the Chinese Liao Dynasty.

\section{THE YEARS OF BEGINNING AND END OF THE WESTERN LIAO DYNASTY}

Liao Dynasty was established by the Khitan aristocracy. At the beginning of the 10th century, the Khitan nationality rose. In 916, the State of Khitan was established in northern China. In 937, it was renamed Daliao. By 1125, Emperor Tianzu died as well as Liao. Liao Dynasty lasted for more than 200 years. Western Liao (1124-1218) lasted for 95 years. It was the continuation of the Khitan Dynasty after the collapse of Liao Dynasty. It was historically known as the Western Liao Dynasty. It was the regime established by the Khitan people in Xinjiang and Central Asia in Chinese history.

The founder of the Western Liao Dynasty was Yelu Dashi, who was the eighth generation of the Yelu Abaoji, the founding emperor of Liao Dynasty. Although the Yelu Dashi was of royal family, its branches were estranged and could only enter the ruling class by way of official advance. In the fifth Da'an year (1089), Yelu Dashi passed the examination and enrolled as Jinshi at 29. ${ }^{1}$ And he was promoted to Hanlin, for he not only knew Khitan language and Chinese, but also was good at riding and archery, as well as military science. Hanlin in Khitan language was called Linya, so people called Yelu Dashi as Dashi Linya or Linya Dashi. Yelu Dashi fled

Tang Changru's Chronicle of Yelu Dashi, Wei Tefu and Feng Jiasheng's Social History of China - Liao (P. 667) presumed that Yelu Dashi was born in the third Da'an Year of Emperor Daozong (1087). According to recording of History of Khitan on page 161, the state of Liao made an exception to admit Khitan Jinshi at the end of Liao Dynasty. Yelu Dashi was ever Jinshi. 
when Liao Dynasty was about to perish. He became king in 1124 and arrived at Kedun City (now the Uyghur City of Qingtorogai in Burgan Province of Mongolia) to establish a base. In 1132, Yelu Dashi ascended the throne in Yemili City and became emperor, named "Juer Khan", and the ministers respected him as "Emperor Tianyou". In Yanqing, the Western Liao Dynasty was officially established. Later, Western Liao ruled areas including the Western Regions, Mobei, Central Asia and other areas, found capital in Husiwoluduo (today's Brana in the southeast of Tokmak, Kyrgyzstan). In the Battle of Katwan ${ }^{2}$ in 1141, after defeating the Seljuk imperial coalition army, they dominated Central Asia. Turkic and Western historical books called it Qara-Khitay or Kara-Khitan. Gaochang Uyghur, the Western Kala Khanate, the East Kara Khanate and Khwarezm surrendered to the Western Liao Dynasty at her prosperous and powerful period. After the death of Yelu Dashi, after three generations of monarchs, Xiaota Buyan, Yelu Yilie and Yelu Pusu, Yelu Zhilugu came to power. Because of the long-term foreign war, the national power of the Western Liao Dynasty declined and was usurped by Kuchlug, a sonin-law of the emperor of the Western Liao.

Kuchlug (?-1218) was the son of Taiyang Khan of the Western Liao Dynasty. After being attacked by Genghis Khan and lost territory, he went to Western Liao and sought refuge with Guer Khan (Yelu Zhilugu). In 1211, he launched a rebellion in the rear while Guer Khan went on an expedition. He overthrew Guer Khan and seized the regime of Western Liao by uniting Khwarezm. Kuchlug honored Zhilugu as Taishang Emperor and Guer Biesu as Empress Mother. At the same time, he declared that he would not change the name of the State of Western Liao and the old system. After the old father-in-law was overthrown, Kuchlug became the supreme ruler of the Western Liao Dynasty. That was the moment when the Western Liao regime was destroyed according to the record. In 1218, Genghis Khan ordered Zhebei to attack the Western Liao Dynasty, and Kuchlug fled to Badakhshan (now within the territory of Tajik Republic). He was captured by local Islamists and sent to Zhebei for execution. His son was Changwen whose son was Chaosi. Before that, the ancient Uyghur regime in the southeast of Tianshan Mountains had surrendered to Genghis Khan. After that, the regimes of Chemalhan and Khwarezm declared their independence on the basis of their earlier conspiracy agreement with Kuchlug. After the ruling of Kuchlug, the only one loyal to him was the eastern Kara Khan State in Kashgar.

Because of the distance of gobi between the Jin Dynasty and the Western Liao Dynasty, the Jin Dynasty was unable to exterminate the Western Liao Dynasty. So it gradually turned from the initial expedition to close attention and defense, especially concerning the relationship between the

\footnotetext{
2 The Battle of Katwan was a war between the Western Liao Dynasty, the Karluks and the Seljuk Empire Coalition Army. On September 9, 1141, it happened in the Katwan Grassland, in the north of Samarkand. The Seljuk Imperial Army was defeated, and the force withdrew from Transoxiana. The Battle of Katwan was also the second confrontation between East Asian civilization and Islamic civilization in history after the Battle of Talas in 751.
}

Western Liao Dynasty and the Western Xia Dynasty, so as to prevent the collusion between them from threatening the Jin Dynasty. $^{3}$

After the rise of the Mongolia Empire, Western Liao was destroyed by the great Mongolia State in 1218. After the fall of the Western Liao Dynasty, the Khitan aristocrat Bohrenhei went to Kerman, Persia, and was first adopted by Khorazm Sultan. In 1224, he established the Erman Dynasty, which is located in the area of Kermansha and Huroshan in Iran today, also known as the "Post-Western Liao Dynasty". This was also the last regime established by the Khitan in history. In 1259, he surrendered to Mongolia, and was awarded the title of Kuruhan. It was annexed by Ilkhanate in 1306. In 1309, Western Liao was completely destroyed.

If the Western Liao Dynasty and the Qierman Dynasty lasted more than 180 years jointly, the influence of the Khitan Dynasty in Central Asia cannot be ignored in terms of time span. Up to now, the Kazakh and Kirgiz (Kyrgyzstan) peoples living in the territory of former Western Liao have retained independent Qita (Khitan) tribes. Even in Kirgiz, Qita is an important tribe with a large population and great influence. It can be said that after the death of the Western Liao Dynasty, the Karachitans still lived in Balasaghun, the capital city of the Western Liao Dynasty, (now the city of Bradoneji in Kyrgyzstan). For example, among royal descendants of their kingdom, the family name of them is Juerhan, called Family Ju. With a complete tribal organization, they joined into Kazakhstan and Kirgiz.

\section{THE TERRITORY, VASSAL STATES AND THE NORTH AND SOUTH OFFICIAL SYSTEMS OF WESTERN LIAO DYNASTY}

Western Liao had a vast territory with a large number of dependent countries and affiliated tribes besides its territorial jurisdiction. The territory under the jurisdiction of the Western Liao Dynasty was centered on Husiwoer. It extended north to the Ili River, south to the upper reaches of the Syr River, west to Talas and east to Balshan (now southeast of Lake Iseka). Its vassals were the West Kara Khanate, the East Kara Khanate, the Gaochang Uyghur and the Khwarezm. The main affiliated tribes were Nianbaenbu (Naiman Tribe), Kangli Tribe and Karluks. Including the vassal states and affiliated tribes, the territory of the Western Liao Dynasty extended eastward to the Tula River, including the area around Kedun City. The eastern boundary of the Western Liao Dynasty retreated to the eastern boundary of Gaochang Uyghur, a vassal state, after Naiman Tribe and Kelie Tribe moved to this area. The northeast boundary was Qianhe River, adjacent to Kyrgyzstan. ${ }^{4}$ In 1175 , due to the affiliation of Nianbaen Tribe to the Jin Dynasty, it retreated to the Altai Mountains, crossed the Balkhash Lake in the northwest, including the areas where the Konli people lived, went west to the Aral Sea, the Ustieultra Plateau and the

See Zhou Feng, Management Strategies of Jin Dynasty for the Western Frontier: Centering on Western Xia and Western Liao Dynasty, Northeast History and Geography, No. 4, 2009, P. 23-28.

$4 \quad$ See Deng Ruiling's Territory of Western Liao Dynasty, National Studies, No. 2, 1980, 31-38. 
Karakum Desert, including Khwarezm; and the western part of the South was bounded by the Amu River, which was successively adjacent to the Seljuk Empire and the Gur Dynasty. The middle section included the Wakhan Corridor. The eastern section was bounded by Karakoram Mountain, Kunlun Mountain and Altun Mountain, and bordered on Tubo and Huangtouhuihe. The southeast section included Hami and Ruoqiang. Being separated by the Taklimakan Desert, it was adjacent to Western Xia.

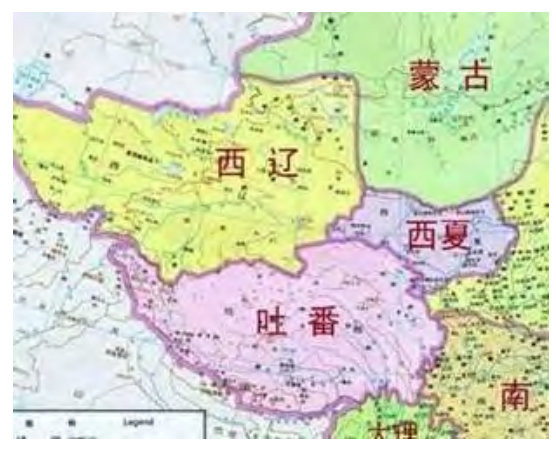

Fig. 1. Map of the Territory of the Western Liao Dynasty.

Apart from the territory directly under the jurisdiction, Western Liao had many dependency states. Western Liao retained the independence and system of these vassal states and gave them great independence. In these vassal states, Western Liao basically did not garrison the troops. It was only required by the vassal states to help them suppress the domestic rebellion. Juer Khan gave them a silver medal as a sign of surrender. According to the importance and loyalty of these states, the Western Liao adopted different management policies. For example, it gave Burhan Dynasty a complete autonomous right, arranged Permanent Shahana (the minor supervisor in charge of supervising the country) in the capital and supervised its military and administration in the Eastern, Western Kara Khanate and Gaochang Uyghur, regularly sent official to understand the situation of Khwarezm and collect annual tribute.

The implementation of the southern and northern official system in Western Liao Dynasty not only inherited the institutional foundation of the Karahan Dynasty, but also continued the system of the Liao Dynasty. Therefore, the official system of Western Liao Dynasty basically followed the official system of the Karahan Dynasty and the Liao Dynasty, while the vassal states preserved their original systems. The Western Liao Dynasty inherited the two-part system of Liao Dynasty: "there are south officials and north officials. They treat Khitan in Khitan's way and Han people by Han system" 5 "The north officials administrate Gongzhang, tribes and vassal states, while the south officials govern prefectures and counties of Han people, taxation and

History of Jin Dynasty, Vol. 121, The Biography of Niange Hannu: In the second year of Tianhui, Liaoxiang Wentabuye came to surrender and told Dashi came to throne in the north. He adopted the north and south official system. He had ten thousand horses and many livestock. Zhonghua Book Company, 1975. military affairs" ${ }^{\prime 6}$. Settled agricultural tribes were managed by regions, with prefectures and counties set up, and the central government set up south officials to manage military affairs. Floating nomadic people took tribes as administrative units and set up officials to rule; and the central government set up north officials to manage the military affairs of tribes. The north officials mainly governed nomadic tribes. It can be divided into the officials of the court (central government organs), Imperial Zhanggong, Royal Zhanggong, Zhu Zhanggong, Palace Official, Tribal Official, the Husbandry Officials of the Fangchang Bureau, military officers, frontier-guarding officers, marching officers, the officials of vassal. The south officials mainly governed agricultural inhabitants. It was basically according to the Tang system and made some adaptations according to the national conditions. It set court officials, palace officials, Wujing official, Fangzhou official, military officers and frontierguarding officers ${ }^{7}$. With the expansion of power, the connotation of south officials and north officials had changed. Based on the difference of the ruling region and the tribal composition, the rulers of the Western Liao Dynasty adhered to the basic principle of governing according to custom, and implemented two kinds of ruling modes. There were the tribal system under direct jurisdiction and the custodial system under inter-jurisdiction. In addition, there has been the preservation of the dynamic title and honorific title with the characteristics of the Central Plains Dynasty. (As can be seen in "Table I")

TABLE I. The PRESERVATION OF THE DyNAMiC TITLE AND HONORIFIC TITLE IN WESTERN LIAO DYNASTY

\begin{tabular}{|c|c|c|c|c|c|}
\hline \begin{tabular}{|c|}
$\begin{array}{c}\text { Dynastic } \\
\text { Title }\end{array}$ \\
\end{tabular} & \begin{tabular}{|c|}
$\begin{array}{c}\text { Honorific } \\
\text { Title }\end{array}$ \\
\end{tabular} & Name & $\begin{array}{l}\text { Reign } \\
\text { Period }\end{array}$ & Reign Title & Remark \\
\hline Dezong & $\begin{array}{l}\text { Emperor } \\
\text { Tianyou }\end{array}$ & $\begin{array}{l}\text { Yelu } \\
\text { Dashi }\end{array}$ & $\begin{array}{l}1124- \\
1143\end{array}$ & $\begin{array}{l}\text { Yanqing } \\
(1132-1134) \\
\text { Kangguo } \\
(1134-1143)\end{array}$ & founder \\
\hline & $\begin{array}{l}\text { Empress } \\
\text { Gantian }\end{array}$ & $\begin{array}{l}\text { Xiaota } \\
\text { Buyan }\end{array}$ & $\begin{array}{l}1144- \\
1150\end{array}$ & Xianqing & $\begin{array}{l}\text { Empress of } \\
\text { Yelu Dashi } \\
\text { working as an } \\
\text { emperor }\end{array}$ \\
\hline Renzong & & Yelu Yilie & $\begin{array}{l}1150- \\
1163 \\
\end{array}$ & Shaoxing & $\begin{array}{l}\text { Son of Yelu } \\
\text { Dashi }\end{array}$ \\
\hline & $\begin{array}{l}\text { Empress } \\
\text { Chengtian }\end{array}$ & $\begin{array}{l}\text { Yelu } \\
\text { Pusuwan }\end{array}$ & $\begin{array}{l}1164- \\
1178\end{array}$ & Chongfu & $\begin{array}{l}\text { Sister of Yelu } \\
\text { Yilie working } \\
\text { as an emperor }\end{array}$ \\
\hline & & $\begin{array}{l}\text { Yelu } \\
\text { Zhilugu }\end{array}$ & $\begin{array}{l}1178- \\
1211\end{array}$ & Tianxi & $\begin{array}{l}\text { Yelu Yilie's } \\
\text { son, Naiman } \\
\text { Prince, } \\
\text { usurping the } \\
\text { throne }\end{array}$ \\
\hline & & Kuchlug & $\begin{array}{l}1212- \\
1218\end{array}$ & $\begin{array}{l}\text { Tianxi (not } \\
\text { changing } \\
\text { title) }\end{array}$ & $\begin{array}{l}\text { Yelu } \\
\text { Zhilugu's son- } \\
\text { in-law, } \\
\text { Naiman } \\
\text { Prince, was } \\
\text { killed in } \\
\text { Mongolia. } \\
\end{array}$ \\
\hline
\end{tabular}

\footnotetext{
6 History of Liao Dynasty · Baiguanzhi I, Vol. 49, Zhonghua Book Company, 1974.

History of Liao Dynasty · Baiguanzhi I, Vol. 49, Zhonghua Book Company, 1974
} 


\section{ThE NATIONALITIES (TRIBES) AND RELIGIONS IN THE WESTERN LIAO DYNASTY}

Western Liao was a multi-ethnic country, mainly including Khitan people from the mainland of China, Han and other nationalities. There were Persian-speaking Tajiks in the ruling areas, Uyghur in ancient Uyghur, and the Turkic-speaking nomadic nationalities, such as the Karluks, Kangli and Naiman people. There were also Arabs, Persians, Syrians, and Jews and so on from western Asia. As a minority of the population, the Khitan and Han people have long lived and intermarried with the local Uyghur and Turks, adapting to local customs, and accepting the Uyghur and other Turkic culture.

There were many nationalities and many religions in the territory of Western Liao. The ethnic groups living here were Khitan, Han, ancient Uyghur, Karluks, Yaghma, Tajik, Lite, Tubo, Mongolian, and some Uyghur-speaking tribes, Persians, Arabs, Syria, and Jews and so on. Popular religions (or doctrines) included Buddhism, Confucianism, Islamism, Zoroastrianism, Manichaeism, Nestorianism, Taoism, Shamanism, and Judaism and so on. Among them, Islamism and Buddhism were the two major religions and the most influential religions. Western Liao was a non-islamic regime established in the region since Islam was introduced to Central Asia. Western Liao formulated religious policies in accordance with the national and religious status quo from a position conducive to the maintenance of its rule, which was also an important part of its rule policy. Western Liao Dynasty changed the policy of treating Islamism as its national religion and restricting other religions formulated by Qara Khanids, and pursued the policy of religious freedom. At that time, Buddhism, Islam, Nestorianism, Shamanism, Manichaeism and Judaism all developed greatly in the Western Liao Dynasty. The Khitan people believed in Shamanism, and still maintained their belief. Buddhism was popular in the upper reaches of Khitan in the Liao Dynasty and in the Western Liao Dynasty. Buddhism prevailed in the Gaochang Uyghur Kingdom, a vassal state. Nestorianism was spread in Balasaghun area and there were parishes in Kashgar. Judaism prevailed in Samarkand and Khwarezm. As for the local religion, Islam was also respected by Yelu Dashi. He wrote letters to his subordinates in a Muslim way, asking them to act according to the opinions of the local Islamic religious leaders. The religious culture of the country, especially Islamic culture, has also been well respected. ${ }^{8}$ The distribution of Islam and Buddhism was roughly as follows: Islam mainly distributed from the western and southern Xinjiang to Central Asia. The people who believed in Islam were mainly Turkic-speaking people such as Uyghur, Karluks, Yagma, Iranian-speaking Tajik and Lite, as well as West Asian except Jews. Buddhism was mainly distributed in Gaochang Uyghur Kingdom and Northern Tianshan area. The main ethnic groups were Han, Uyghur, Khitan, Tubo and so on. Nestorianism, Taoism, Shamanism and other religions were widely distributed in the areas and nationalities where Islam and Buddhism were prevalent, forming a complex situation in which many religions interlaced and coexisted. In the early period of the establishment of the Western Liao Dynasty, the ruler carried the policy of "defeating the enemies and placating the surrenders". In the prosperous period of the rule of the Western Liao Dynasty, the ruler adopted a more relaxed and moderate policy. In the late period of the rule of the Western Liao Dynasty, the monarch Yale Zhigulu still tried to use Islam to maintain its rule. But after Kushluk usurped the throne, he took a policy of pressure on Islam. The pressure policy resulted in the strong resistance of the majority of Muslims and accelerated the collapse of the Western Liao Dynasty.

\section{The CUlture OF WeStern LiaO DyNASTY}

The founder of West Liao, Yelu Dashi, is a highly educated Khitan aristocracy. After the collapse of the Liao Dynasty, the Western Liao Dynasty claimed to be the lineal Khitans. Besides making necessary adaptations and amendments, the rules and regulations of the Western Liao Dynasty remained stubbornly their own traditions and strongly displayed their own cultural characteristics in all aspects. The rulers of the Western Liao Dynasty promoted the most advanced culture of that time to their newly-built country in order to build the Western Regions into the base of "restoring the old things".

The establishment of the Western Liao Dynasty ended the turmoil and disputes between East Karahan and West Karahan. The rulers of the Western Liao Dynasty, guided by the early Karahan's ruling ideology and Chinese Confucianism, carried the policy of reducing the burden of forced labor and lightening taxes on people, took the policy of placating outlying regions and the regions submitting to her and managing these affiliated vassals, and adopted the policy of following their customs on religious beliefs. It eased the tense class relations, ethnic relations and religious relations and formed a relatively relaxed and peaceful social and political environment. It provided a good social environment for the development of culture. ${ }^{10}$

The establishment of the Western Liao regime is another important period that Chinese culture exerted an important influence in Central Asia. During the Han and Tang Dynasties, a large number of inlanders emigrated from the Western Regions to the Hans. Since the Han Dynasty, the Western Regions had a close relationship with the Central Plains in political, economic and cultural aspects. During the reign of the Western Liao Dynasty, another climax occurred. And even Chinese culture influenced Western Asia and Europe. With the strengthening of cultural exchanges and integration between the East and the West, the official languages of Western Liao were Khitan, Chinese and Persian, and folk people used ancient Uyghur. Various nationalities learned the languages of different nationalities in the process of mutual exchanges and promoted cultural integration. Affected by Arab culture, the ancient Uyghur alphabet was gradually replaced by the Arabic alphabet in the Western Liao Dynasty. During this period, many influential poets were born in ancient Uyghur tribe of Western Liao Dynasty, such as Ahmad Yassevi, Ahmad Bin Mahmud Yukenek, Ahmad Bukharai, Suzani Samarhadi and so on 
During the reign of Western Liao Dynasty, Han culture was widely disseminated in Central Asia. Since a large number of Han people were in the army of Yelu Dashi's Western Expedition, they played an important role in disseminating Han culture with the Khitans after they settled in Western Liao. According to Journey to West of Changchun Taoist, "primitively local people get water with jars and put on their shoulder. When they saw water appliance of Han people, they amazed that: all things of Taohuashi are good. Taohuashi means Han people". Here it only listed an example that Han people introduced windlass to the Western Regions. Local people clearly pointed out that "all things of Han people are nice", which shows that many advanced technologies were introduced. In Samarkand, Changchun saw Han craftsmen mixed in the city. There were also Han people in villages. Some were landlords and some were peasants. Chang De also saw many Han people living with local people, when he was sent to the Western Region. ${ }^{\text {I }}$ In addition, the emperor of the Western Liao Dynasty used Chinese year title and dynamic title, and the official languages also contained Chinese. In terms of administration, military affairs, taxation, production technology, architectural art, religious beliefs and living customs, Han culture influenced Central Asia in many ways. ${ }^{12}$ Archaeological data prove that there were well-developed smelting and weapons manufacturing industries in the territory under the jurisdiction of the Western Liao Dynasty. Arrows, axes, knives, short swords and armor were found everywhere. Craftsmen used advanced forging technology of the Central Plains to produce steel weapons. In terms of architectural decoration, it embodies the characteristics of the integration of Han art and Han culture with Central Asian culture, such as tile, clay sculpture and warm kang. In the ancient city of Alexander, the representative Far-East building materials were found: square tiles and gray semicircular tiles. Eaves tiles were also found here. There are patterns on the tile, the Buddha sitting in the center, and the Bodhisattva around. There are paintings and decorative walls in the temple in Han style. Buddha statues not only have models of Han art, but also have the characteristics of ancient Indian art. In addition, the two large-scale Islamic Mausoleums in Blanta and Uzgen near Tokamak are all wellpreserved Islamic buildings of the Western Liao Dynasty. During this period, the landscape art in Transoxiana has also been highly developed, as can be seen from the poems written by Yelu Chucai and Qiu Chucai in praise of the local landscape art.

\section{THE LITERATURE OF WESTERN LIAO DYNASTY}

The official words and language of the central government of Western Liao were Chinese. Russian Scholar Barthold ${ }^{13}$ believed and Mr. Chen Yuan also concluded that "the five leaders of the Western Liao all had Chinese year title. It can be seen that they the government in the Western Regions used Chinese"14. According to the names of the government organizations and some official names of the Western Liao Dynasty, especially from the texts preserved in the Beginning and End of the Western Liao, Vol. 3 of History of Liao Dynasty, the Western Liao Dynasty did use Chinese. They also used Khitan language and writing, which can be seen from Li Shichang, a Chinese scholar in the late Western Liao Dynasty, who taught Yelu Chucai Khitan language and translated Song of Drunken Righteousness, written by Sigong Master of Liao Dynasty, into Chinese ${ }^{15}$. A Han official could speak Khitan language, so Khitan officials and the people of Khitan should know Khitan language, and it should also be the language commonly used by the government, just like in the Liao Dynasty. Turkic language was a common language of the local people. In order to meet the needs of life exchange and political rule, both common people and the ruling group would learn it. From a fact recorded in the History of Yuan Dynasty: Juer Khan of the Western Liao Dynasty invited Harayi Hachibeilu, a Uyghur from Gaochang, to teach his son in Balashahun ${ }^{16}$. They may not only learn ancient Uyghur language. But ancient Uyghur language was undoubtedly the main course of study. Khitan people in Central Asia should have mastered the Turkic language generally. So after the death of Western Liao, they wore Uyghur clothes ${ }^{17}$, and jointed into the local tribes. From the instruments of the central government of the Liao Dynasty, it can be seen that they have used Persian instruments in the period of Yelu Dashi ${ }^{18}$. The vassals and local governments used local languages as official languages. According to Record of Envoy to North, its local documents also were written by ancient Uyghur. This is also confirmed by unearthed documents in Turpan, Dunhuang.

Now we know that a lot of works, like Sigong Master's Song of Drunken Righteousness, are preserved in Chinese translation version, organized by Yelu Chucai. Other Khitan writings were abundant at that time. Taking Song of Drunken Righteousness as an example, it is also known that there were many excellent works. Due to the death of Khitan script, the written works of Khitan have long been lost in the dust of history. At present, the written works in Khitan still need to be explored.

The writings in Chinese during the Western Liao Dynasty preserved some speeches and edicts of Yelu Dashi in Chinese in the History of Liao Dynasty.

From 12th Century to early 13th Century, some Turkic works were preserved. Ahmad Yassevi wrote a collection of theological poetry, Diwan-I Hikmet, in Turkic. Ahmad Yassevi was a famous scholar of Sufistic School, theologian and poet. Legend has it that he was born in the city of Selan (Isfajab), learning from the Islamic missionary Alslan-Baba (Bab Alslan), and died in 562 of Islamic calendar (11661167). As a sufistic scholar, his poems advocated abstinence and submission, and also preserved some historical materials of cultural history and social customs. Ahmad Yassevi had many students and successors. They also wrote in Turkic. One of the most famous was Hakim Arta (Suleiman Bagelgani). He wrote a collection of Sufist doctrines in prose. Ahmad Yassevi played a very important role in propagating Islam. He made some changes to the original doctrine according to the customs and habits of the Turkic people, and was called the "Yassevi faction". Another long exhortational theological poem, An Introduction to Truth, written in the late years of the Western Liao Dynasty, was written by Ahmad Jagnek, a blind man. He dedicated his poem to Immer Mohammed, Kara Khan in Kashgar at that 
time. The author wrote the poem in the most popular ancient Uyghur language at that time, totaling 484 lines, divided into 14 chapters, plus 28 lines of postscript poems of later generations. As a long exhortational poem, it first emphasizes the importance of knowledge, preaches with various metaphors, and requires people to love learning. The poem also boldly exposes the hypocrisy of the rulers and complains about social injustice, encourages people to be upright, and castigates such bad habits as greed, parsimony, arrogance, lying and boasting, love of leisure and hate of work. Generosity, humility, prudence, kindness and courtesy are praised in the poem. As a religious exhortation, there must be lots of fatalistic views. Although the works are elucidated, it is not dull to read by skillful use of such rhetorical devices as metaphor, comparison, contrast, counter-criticism, parallelism and so on.

In Transoxiana in the West Liao Dynasty, there were also some talented poets. Among them, Amark Bukharai (died in 1149) and Suzani Samarhadi (died in 1173) were the most famous. Amark's poems were good, becoming the rhetoric guide and the model of poetry writing for Tajik poets.

\section{CONCLUSION}

The regional culture of Western Liao Dynasty determined its multi-ethnic and multi-lingual characteristics. From the content theme of its literature, there were political edicts of the ruling class, the writings of the general bureaucrats or literati, and religious articles that mostly express religious plots or aim directly at persuasion. Most of literary form is poetry, in popular style. Most of religious literature aims at preaching and reasoning, which has become an important characteristic of the literature. These literary factors were brought into the Central Plains by a large number of Semu people who moved to the Central Plains with army or for business by the rise of the Mongolian Empire and the demise of the Western Liao Dynasty. These literature factors also were brought into Semu people in the early Yuan Dynasty. So, there was a direct relationship between the culture of Semu people and the culture foundation of the Western Liao Dynasty.

\section{REFERENCES}

[1] Zhou Feng, Management Strategies of Jin Dynasty for the Western Frontier: Centering on Western Xia and Western Liao Dynasty, Northeast History and Geography, No. 4, 2009, P. 23-28. (in Chnese)

[2] Deng Ruiling, Territory of Western Liao Dynasty, National Studies, No. 2, 1980, 31-38. (in Chnese)

[3] Baiguanzhi, History of Liao Dynasty I, Vol. 49, Zhonghua Book Company, 1974. (in Chnese) 